\title{
Ustugi zdalne w polskich bibliotekach uniwersyteckich
}

\section{Wprowadzenie}

$\mathrm{K}^{\circ}$ onieczność adaptacji nowych technologii do bibliotek nie budzi obecie większych zastrzeżeń. Wystarczy wspomnieć choćby o zwiększeniu atrakcyjności i konkurencyjności oferty bibliotecznej, skróceniu czasu obsługi czytelnika czy wprowadzeniu nowych form rozpowszechniania informacji, by do nowoczesnych technologii w bibliotekarstwie przekonać największych sceptyków. Oczywiście, nie pojawiły się one w bibliotekach z dnia na dzień. Najpierw sukcesywnie wykorzystywano telefon, potem faks, komputer i źródła elektroniczne, a wreszcie sieć Internet. W związku z możliwościami, jakie stwarzały nowoczesne technologie, z czasem użytkownikom zaczęto oferować realizację usług nie tylko lokalnie - w siedzibie biblioteki, ale także zdalnie. W ostatnich latach sfera tych nowych usług informacyjnych zaczęła tak intensywnie ewoluować, że w przypadku wielu amerykańskich bibliotek akademickich doprowadziła do reorganizacji struktur bibliotecznych. Przeobrażenia nie ominęły także polskich bibliotek. W obliczu powszechnej globalizacji i one stanęły przed koniecznością wdrażania usług wykorzystujących najnowsze narzędzia technologiczne. W tym kontekście warto zbadać, jak prezentuje się oferta usługowa tych placówek, tzn. jakie typy usług są w nich świadczone, jaka jest ich jakość i czy poziom ich realizacji jest zgodny z oczekiwaniami użytkowników. Po-

* Uczestniczka studiów doktoranckich z zakresu bibliologii, prowadzonych na Wydziale Nauk Historycznych Uniwersytetu Mikołaja Kopernika w Toruniu. 
nieważ omówienie dokonań wszystkich polskich bibliotek w tym zakresie przekroczyłoby znacznie ramy niniejszego artykułu, autorka ograniczyła się do zebrania i uporządkowania przykładów usług znajdujących się w ofercie bibliotek polskich uniwersytetów, a następnie do ich analizy pod kątem przydatności i możliwości rozbudowy.

\section{Typologia ustug bibliotecznych}

W zależności od miejsca fizycznej obecności usługobiorcy można wyróżnić trzy rodzaje usług bibliotecznych: lokalne, zdalne i hybrydowe. Część z nich (np. dostęp do komercyjnych baz danych) może być świadczona wieloma sposobami jednocześnie, tj. na odległość (za pomocą Internetu) lub stacjonarnie (w siedzibie danej biblioteki), część - wyłącznie lokalnie (np. udostępnianie książek w czytelni).

Ponieważ realizacja usług lokalnych wymaga obecności usługobiorcy w określonym miejscu i czasie, mogą być one świadczone tylko na miejscu, w budynkach bibliotek. Doskonałym przykładem realizacji tej formy działalności są wspomniane wcześniej udostępnianie zbiorów w czytelni czy zamawianie woluminu danego tytułu za pomocą papierowego rewersu. Z tej grupy świadczeń nie należy jednak wykluczać usług wspartych różnymi technologiami. Lokalny charakter może mieć więc także np. zapewnianie dostępu do stanowisk komputerowych podłączonych do Internetu znajdujących się na terenie biblioteki.

Usługi zdalne stanowią tę część oferty biblioteki, która może być świadczona całkowicie poza jej siedzibą. W tym przypadku użytkownik (zdalnie) za pośrednictwem różnych technologii (telefonu, faksu, Internetu) lub tradycyjnej poczty uzyskuje dostęp do wybranych usług. Za przykład tego rodzaju świadczeń można uznać choćby udzielanie odpowiedzi na różnego typu kwerendy listownie, telefonicznie, za pośrednictwem faksu lub za pomocą komunikatora internetowego (np. Gadu-Gadu, Skype).

Nie każdą usługę można jednak bezdyskusyjnie zaklasyfikować do jednej z wyżej wymienionych grup, co ilustruje np. procedura rejestracji nowych użytkowników. Usługa ta może mieć charakter lokalny, gdy konto nowego czytelnika zakłada bibliotekarz w jego obecności, lub zdalny, gdy czytelnik - np. za pomocą formularza WWW udostępnionego na stronie internetowej biblioteki - samodzielnie wprowadza swoje dane. Choć tok postępowania wydaje się bardzo prosty, trudności przysparza sama czyn- 
ność rejestracji, której nie można jednoznacznie zaklasyfikować. Z jednej strony polega ona bowiem na wprowadzeniu danych za pomocą formularza WWW przez użytkownika, z drugiej - na weryfikacji danych w siedzibie biblioteki przez jej pracownika w obecności użytkownika. Sposobem na pewne rozwiązanie problemu typologii usług jest podzielenie ich na etapy. W przypadku usługi założenia konta nowemu użytkownikowi mogą to być: zdalne wprowadzenie danych i ich lokalna weryfikacja. Podział danej usługi na poszczególne etapy nie zawsze można uznać jednak za zasadny. Przy dużej liczbie czynności może to doprowadzić do niepotrzebnego nieładu. Należy zatem przyjąć możliwość istnienia usług hybrydowych, czyli świadczonych częściowo zdalnie z koniecznością fizycznej obecności usługobiorcy w bibliotece.

\section{Metodologia badań}

Z e względu na to, że strona internetowa biblioteki stanowi dobry punkt startowy dla usług zdalnych, zwłaszcza że większość z nich przybiera formę elektroniczną, materiałem badawczym dla autorki stały się strony internetowe bibliotek tych uniwersytetów, które zostały uwzględnione w wykazie publicznych uczelni akademickich Ministerstwa Nauki i Szkolnictwa Wyższego ${ }^{1}$. W szczególności były to:

1. Uniwersytet Gdański (dalej: UG),

2. Uniwersytet im. Adama Mickiewicza w Poznaniu (dalej: UAM),

3. Uniwersytet Jagielloński w Krakowie (dalej: UJ),

4. Uniwersytet Kardynała Stefana Wyszyńskiego w Warszawie (dalej: UKSW),

5. Uniwersytet Kazimierza Wielkiego w Bydgoszczy (dalej: UKW),

6. Uniwersytet Łódzki (dalej: UŁ),

7. Uniwersytet Marii Curie-Skłodowskiej w Lublinie (dalej: UMCS),

8. Uniwersytet Mikołaja Kopernika w Toruniu (dalej: UMK),

9. Uniwersytet Opolski (dalej: UO),

10. Uniwersytet Rzeszowski (dalej: UR),

11. Uniwersytet Szczeciński (dalej: US),

${ }^{1}$ Publiczne uczelnie akademickie. W: Wykaz uczelni publicznych nadzorowanych przez Ministra właściwego ds. szkolnictwa wyższego [on-line]. Ministerstwo Nauki i Szkolnictwa Wyższego [dostęp 15 lipca 2009]. Dostępny w World Wide Web: http://www.nauka.gov. $\mathrm{pl} / \mathrm{mn} /$ index.jsp?place $=$ Lead08\&news_cat_id=948\&news_id=3610\&layout=2\&page $=$ text. 
12. Uniwersytet Śląski w Katowicach (dalej: UŚ),

13. Uniwersytet w Białymstoku (dalej: UwB),

14. Uniwersytet Warmińsko-Mazurski w Olsztynie (dalej: UWM),

15. Uniwersytet Warszawski (dalej: UW),

16. Uniwersytet Wrocławski (dalej: UWr),

17. Uniwersytet Zielonogórski (dalej: UZ).

\section{Autorskie badania bibliotek - wyniki sumaryczne}

szystkie, zidentyfikowane na podstawie analiz stron internetowych, przykłady zdalnych usług realizowanych przez biblioteki uniwersyteckie prezentuje poniższa tabela.

Tabela. Usługi zdalne i hybrydowe oferowane w polskich bibliotekach uniwersyteckich

\begin{tabular}{|c|c|c|c|c|c|c|c|c|c|c|c|c|c|c|c|c|c|c|}
\hline \multirow[b]{2}{*}{ 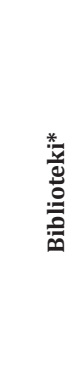 } & \multicolumn{17}{|c|}{ Usługi } & \multirow[b]{2}{*}{$\stackrel{\pi}{\Xi}$} \\
\hline & 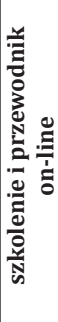 & 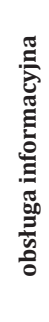 & $\frac{\pi}{\frac{\pi}{2}}$ & 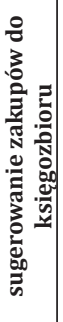 & 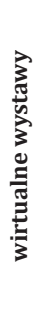 & 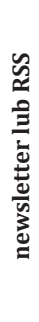 & 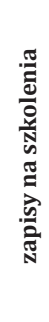 & 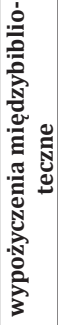 & 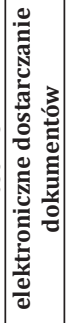 & 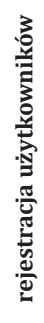 & 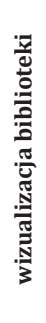 & 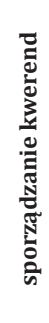 & $\Xi$ & $\frac{\frac{0}{0}}{\frac{x}{0}}$ &  & 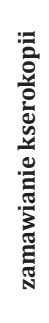 & 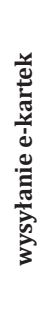 & \\
\hline 1 & 2 & 3 & 4 & 5 & 6 & 7 & 8 & 9 & 10 & 11 & 12 & 13 & 14 & 15 & 16 & 17 & 18 & 19 \\
\hline UWr & S & $\mathrm{K}$ & $X$ & & & $\mathrm{~N}$ & $\mathrm{E}$ & W & $X$ & $\mathrm{X}$ & & W & & $X$ & $X$ & & & 11 \\
\hline UAM & $S$ & W & $X$ & $\mathrm{E}$ & & & EW & & & & & WE & & & & WE & & 7 \\
\hline UR & & KW & $X$ & & & $\mathrm{R}$ & $\mathrm{K}$ & & & $\mathrm{X}$ & & & $X$ & & & & & 6 \\
\hline UW & $S$ & & & & $X$ & $\mathrm{R}$ & & & & & $\mathrm{F}$ & & & $\mathrm{X}$ & & & $X$ & 6 \\
\hline US & $\mathrm{P}$ & $\mathrm{K}$ & & & $X$ & & & & & $\mathrm{X}$ & & & $X$ & & & & & 5 \\
\hline UŚ & $\mathrm{P}$ & W & & W & $X$ & & & & & & $3 \mathrm{D}$ & & & & & & & 5 \\
\hline UMK & $\mathrm{P}$ & KW & & & & $\mathrm{R}$ & & W & $X$ & & & & & & & & & 5 \\
\hline UWM & $S$ & & $X$ & WE & & & & E & & & & & & & & & & 4 \\
\hline UwB & S & & $X$ & & & & & & $\mathrm{X}$ & & & & & & & & & 3 \\
\hline UG & S & $\mathrm{K}$ & & & $X$ & & & & & & & & & & & & & 3 \\
\hline UKW & $\mathrm{P}$ & W & & W & & & & & & & & & & & & & & 3 \\
\hline UMCS & S & & & W & & & & & & & $3 \mathrm{D}$ & & & & & & & 3 \\
\hline
\end{tabular}


Tabela. Usługi zdalne i hybrydowe oferowane w polskich bibliotekach uniwersyteckich (ciąg dalszy)

\begin{tabular}{|l|c|c|c|c|c|c|c|c|c|c|c|c|c|c|c|c|c|c|}
\hline \multicolumn{1}{|c|}{1} & $\mathbf{2}$ & $\mathbf{3}$ & $\mathbf{4}$ & $\mathbf{5}$ & $\mathbf{6}$ & $\mathbf{7}$ & $\mathbf{8}$ & $\mathbf{9}$ & $\mathbf{1 0}$ & $\mathbf{1 1}$ & $\mathbf{1 2}$ & $\mathbf{1 3}$ & $\mathbf{1 4}$ & $\mathbf{1 5}$ & $\mathbf{1 6}$ & $\mathbf{1 7}$ & $\mathbf{1 8}$ & $\mathbf{1 9}$ \\
\hline UKSW & $\mathrm{P}$ & & $\mathrm{X}$ & & & & & & & & & & & & & & & 2 \\
\hline UŁ & $\mathrm{S}$ & & & $\mathrm{E}$ & & & & & & & & & & & & & & 2 \\
\hline UO & & $\mathrm{W}$ & & & & & & & & & & & & & & & & 1 \\
\hline UZ & $\mathrm{P}$ & & & & & & & & & & & & & & & & & 1 \\
\hline Suma & 14 & 9 & 6 & 6 & 4 & 4 & 3 & 3 & 3 & 3 & 3 & 2 & 2 & 2 & 1 & 1 & 1 & 67 \\
\hline
\end{tabular}

* Nazwy uniwersytetów, w których funkcjonują badane biblioteki, zostały uporządkowane w tabeli malejąco, tj. według liczby oferowanych usług.

Objaśnienia do tabeli:

$\mathrm{P}$ - przewodnik on-line po bibliotece,

$\mathrm{S}$ - szkolenie biblioteczne on-line,

$\mathrm{K}$ - komunikator internetowy,

$\mathrm{W}$ - formularz WWW,

E - poczta elektroniczna (e-mail),

$\mathrm{N}$ - newsletter,

$\mathrm{R}$ - kanał RSS,

F - film,

3D - trójwymiarowa wizualizacja budynku,

$\mathrm{X}$ - obecność danej usługi.

Źródło: opracowanie własne.

Jak wynika z tabeli, ogółem wyróżniono 17 typów usług zdalnych, które doczekały się 67 realizacji w 16 bibliotekach. Liczby zamieszczone w ostatniej kolumnie tabeli wyraźnie dowodzą, że najbogatszą ofertą usługową dysponuje obecnie Biblioteka Uniwersytecka we Wrocławiu, która proponuje swoim użytkownikom aż 11 rodzajów świadczeń zdalnych. Na dalszych miejscach plasują się biblioteki UAM (z 7 usługami) oraz UR i UW (z 6). Pozycję kolejną zajmują ex aequo biblioteki US, UŚ i UMK (po 5 usług). Pozostałe placówki oferują cztery i mniej rodzajów świadczeń. Jak nietrudno zauważyć, wykaz nie uwzględnia Biblioteki Jagiellońskiej, która jako jedyna z badanych bibliotek - poza prowadzeniem własnej strony WWW, zapewnieniem dostępu do katalogu on-line, organizacją zasobu elektronicznego oraz udzielaniem informacji telefonicznej i za pośrednictwem poczty elektronicznej - nie oferuje żadnych z wyszczególnionych w tabeli usług.

Poniżej zaprezentowano szczegółowe omówienie przykładów świadczonych przez biblioteki usług, dokonując ich podziału na usługi eduka- 
cyjne, informacyjne oraz usługi o charakterze promocyjnym i związane z udostępnianiem zbiorów.

\section{Autorskie badania bibliotek - wyniki szczególowe}

W szystkie badane biblioteki uniwersyteckie mają stronę WWW i publicznie dostępny katalog on-line umożliwiający przeszukiwanie, a w większości także zamawianie woluminów, przedłużanie terminu zwrotu wypożyczonych pozycji oraz sprawdzanie konta czytelnika. Ponadto każda $\mathrm{z}$ bibliotek dysponuje zasobem elektronicznym (np. bazy danych, dokumenty elektroniczne, polecane adresy internetowe), który jest udostępniany na odległość (w zależności od licencji) wszystkim lub wybranym grupom użytkowników. Za standard w bibliotekach uniwersyteckich uznano także świadczenie usług informacyjnych przez telefon i pocztę elektroniczną.

Z grupy usług edukacyjnych najczęściej (14 przykładów) oferowane są przewodniki lub szkolenia biblioteczne w formie kursu na platformie e-learningowej Moodle, prezentacji multimedialnej albo strony WWW. Ponadto 3 biblioteki proponują użytkownikom zapisywanie na szkolenia za pośrednictwem poczty elektronicznej, formularza WWW lub komunikatora Gadu-Gadu. Biblioteka UAM jako jedyna udostępnia oba te kanały komunikacyjne. Ponieważ przysposobienie biblioteczne może przebiegać zdalnie aż do momentu konieczności otrzymania przez uczestnika stosownego wpisu do indeksu (tylko końcowy etap musi odbyć się lokalnie), wprowadzenie tej usługi do polskich bibliotek uniwersyteckich należy uznać za rozwiązanie słuszne, także w kontekście zalet szkoleń online. $\mathrm{Z}$ reguły trwają one krócej, łatwiej je zorganizować i przeprowadzić (bez konieczności zwracania uwagi na ograniczenia lokalowe lub personalne) czy zadbać o zachowanie standardów i jakość kształcenia².

Wyniki badań dowodzą, że polskie biblioteki uniwersyteckie na odległość świadczą także usługi informacyjne. Ponad połowa (9) z nich udziela informacji przez komunikator Gadu-Gadu lub/i formularz WWW. Tylko 2 (UWr i UAM) oferują jednak usługę zamawiania kwerend bibliotecznych, bibliograficznych lub rzeczowych przez pocztę elektroniczną

${ }^{2}$ R. Moczadło, Kurs online z przysposobienia bibliotecznego - studium przypadku. E-mentor [on-line] 2008, 5 (27) [dostęp 15 lipca 2009]. Dostępny w World Wide Web: http://www.e-mentor.edu.pl/artykul_v2.php?numer=24\&id=535. 
lub specjalny kwestionariusz WWW. Działalność informacyjna prowadzona zdalnie w polskich bibliotekach uniwersyteckich obejmuje ponadto informowanie czytelnika o zbiorach własnych i innych bibliotek, choćby w postaci odsyłaczy do ich stron internetowych, oraz umożliwienie kontaktu z biblioteką za pośrednictwem poczty elektronicznej.

Niestety, oferta zdalnych usług informacyjnych polskich bibliotek jest dość skromna. Z danych uzyskanych w badaniach Megapanel PBI/Gemius $^{3}$ za lipiec 2008 r. wynika, że największą popularnością wśród użytkowników sieci (40\%) cieszy się komunikator Gadu-Gadu. Oprócz niego 29\% użytkowników korzysta z komunikatora Skype, a 6\% - Tlen.pl ${ }^{4}$. Poza Biblioteką Główną Akademii Medycznej w Gdańsku, która wykorzystuje oba komunikatory, polskie biblioteki zdają się jednak nie dostrzegać tych zwiększonych możliwości docierania do czytelnika. Rozszerzenie oferty o dodatkowe komunikatory wiąże się oczywiście z koniecznością zainstalowania i nauki obsługi dodatkowego oprogramowania, lecz nie powinno zniechęcać bibliotekarzy. Aby ułatwić nawiązywanie kontaktu z użytkownikiem, można przecież zrezygnować z wykorzystywania kilku komunikatorów na rzecz jednego multikomunikatora (np. Miranda, Konnekt, AQQ), obsługującego różne protokoły jednocześnie (czasem także serwis SMS). Innym sposobem jest umieszczenie na stronie WWW biblioteki programu umożliwiającego zadawanie pytań przez użytkowników i udzielanie odpowiedzi przez pracowników synchronicznie, bezpośrednio ze strony internetowej i co najważniejsze - bez konieczności posiadania konta lub komunikatora na komputerze użytkownika (np. program meebo me).

Być może dobrym rozwiązaniem dla polskich bibliotek byłoby także wprowadzenie usług informacyjnych świadczonych za pośrednictwem

${ }^{3}$ Megapanel PBI/Gemius to badanie panelowe polskiego Internetu, stanowiące standard pomiaru oglądalności witryn internetowych w Polsce, a prowadzone na zlecenie PBI przez firmę Gemius SA. Megapanel PBI/Gemius jest badaniem dostarczającym informacji na temat preferencji i zachowań polskich internautów w sieci. Wyniki stanowią narzędzie pracy wydawców internetowych, domów mediowych i firm prowadzących działania marketingowe i biznesowe w Internecie. Są także podstawą do tworzenia analiz na temat rozwoju rynku internetowego w Polsce. W badaniu biorą udział wszystkie najbardziej znaczące w Polsce witryny i portale internetowe. Mechanizm działania polega na umieszczeniu w treści strony odnośnika do licznika PBI/Gemius, co powoduje, że aktywność użytkowników jest zliczana niezależnie przez zewnętrzny podmiot. Cyt. za: Megapanel PBI/Gemius. W: Wikipedia. Wolna Encyklopedia [on-line] [dostęp 15 lipca 2009]. Dostępny w World Wide Web: http://pl.wikipedia.org/wiki/Gemius.

${ }^{4}$ Wyniki Megapanel PBI/Gemius za lipiec 2008 r. [on-line]. Gemius S.A. [dostęp 15 lipca 2009]. Dostępny w World Wide Web: http://pliki.gemius.pl/Komunikaty/2008/Wyniki_Megapanel_PBI_Gemius_lipiec_2008. 
serwisów SMS lub oprogramowania pozwalającego na porozumiewanie się w czasie rzeczywistym (tzw. Web Contact Center). Takie usprawnienia funkcjonują już w wielu bibliotekach zagranicznych (jak np. Sims Memorial Library, Yale University Science Libraries, State Library of Ohio, Library of Congress, University of Central Florida Libraries) i z powodzeniem spełniają swoją rolę. Najwięcej zalet ma oprogramowanie Web Contact Center. Mimo że jego adaptacja wymaga promocji, szkoleń i nakładów finansowych, dzięki niemu usługi informacyjne są dostępne z każdego miejsca i na czas 5 .

Poza usługami edukacyjnymi i informacyjnymi polskie biblioteki uniwersyteckie oferują także zdalne usługi o charakterze promocyjnym. Można do nich zaliczyć: tworzenie i udostępnianie galerii zdjęć z uroczystości lub imprez (8 bibliotek), prezentację wystaw wirtualnych (4), rozsyłanie wiadomości za pomocą newslettera lub kanałów RSS (4), tworzenie różnych form wizualizacji na stronie biblioteki (3), uruchamianie forum i sklepu internetowego (po 2) oraz umożliwienie wysłania kartki elektronicznej ze zdjęciami z biblioteki (1). Aż 12 z 16 objętych badaniem bibliotek (75\%) wprowadziło co najmniej jedną z wyżej wymienionych usług promocyjnych. Może to świadczyć o tym, że biblioteki te coraz większą wagę przywiązują do promocji swoich placówek, a formy zdalne stanowią atrakcyjne jej uzupełnienie.

Usługi związane z udostępnianiem zbiorów są z reguły realizowane zdalnie głównie w ramach publicznie dostępnego katalogu on-line. Ponieważ znacznie usprawnia on pracę bibliotekarzy, posiadają go wszystkie badane biblioteki uniwersyteckie. Zdalną aktywację bądź rejestrację użytkowników umożliwiają tylko $3 \mathrm{z}$ nich (w bibliotece UR odbywa się to częściowo lokalnie). Z uwagi na to, że podczas rejestracji użytkowników na odległość może dochodzić do powstawania błędów (będących skutkiem przypadku lub celowego działania), zachowanie procedur weryfikacji danych nowych użytkowników przez bibliotekarzy, jak ma to miejsce w badanych placówkach, wydaje się konieczne. Z innych usług związanych z udostępnianiem zbiorów 3 biblioteki oferują elektroniczne dostarczanie kopii dokumentów, a 1 (biblioteka UAM) - przesyłanie zamówionych w Internecie kopii tradycyjną pocztą. Ponad 1/3 badanych bibliotek (6)

${ }^{5}$ Więcej na ten temat: L. Derfert-Wolf, Elektroniczne usługi informacyjne typu pytanie-odpowiedź - światowe trendy i doświadczenie bibliotek. Biuletyn EBIB [on-line] 2006, nr 3 (71) [dostęp 15 lipca 2009]. Dostępny w World Wide Web: http://www.ebib. info/2006/71/derfert.php. 
stwarza swoim użytkownikom możliwość partycypacji w procesie kształtowania księgozbioru, a więc sugerowania tytułów do zakupu. Interesujący sposób udostępniania materiałów bibliotecznych oferuje biblioteka UWr - digitalizację na żądanie. Usługa ta dotyczy zbiorów specjalnych i można ją zamówić za pośrednictwem formularza WWW, poczty elektronicznej lub faksu. Udostępnianie dokumentów drukowanych bądź ograniczonych licencją (np. komercyjne bazy danych) jest realizowane w polskich bibliotekach uniwersyteckich lokalnie. Biblioteki, w których zasób elektroniczny i kopie dokumentów tradycyjnych są udostępniane całkowicie zdalnie, należą w Polsce jeszcze do wyjątków.

\section{Podsumowanie}

Dealizowane w większości bibliotek polskich uniwersytetów usługi Zzdalne są świadczone głównie za pośrednictwem Internetu. Jak starano się wykazać, ich szeroki wachlarz swym zakresem obejmuje większość zadań zapisanych w Ustawie o bibliotekach ${ }^{6}$ - od gromadzenia i udostępniania materiałów bibliotecznych po ich rozpowszechnianie. Taka forma prowadzenia działalności usługowej stanowi także doskonałe uzupełnienie działalności edukacyjnej biblioteki i służy jej promocji zarówno w obsługiwanym środowisku, jak i poza nim.

Wzrost znaczenia usług zdalnych skutkuje jednak nie tylko wprowadzaniem ich do oferty bibliotek, ale także zwiększonym zainteresowaniem badaczy ich jakością i funkcjonalnością czy standardami kształcenia ich użytkowników ${ }^{8}$. Warto zadać pytanie, czy istnieje ryzyko, że usługi zdalne całkowicie zastąpią lokalne (tradycyjne). Gdyby sytuacja taka nastąpiła, biblioteki jako miejsca rzeczywistych spotkań mogłyby przestać istnieć i zamienić się $\mathrm{w}$ wielkie serwisy internetowe lub obiekty wirtualne

${ }^{6}$ Ustawa z dnia 27 czerwca 1997 r. o bibliotekach, Dz.U. 1997, nr 85, poz. 539.

7 Por. E. Głowacka, L. Derfert-Wolf, Wskaźniki funkcjonalności elektronicznych usług bibliotecznych według raportu technicznego ISO/TR 20983, „Przegląd Biblioteczny” 2006, z. 4, s. 445-460.

${ }^{8}$ Por. A. Grygorowicz, E. Kraszewska, Propozycje standardów w zakresie edukacji użytkowników polskich bibliotek medycznych. W: Kształcenie użytkowników naukowej informacji medycznej - koncepcje i doświadczenia, Lublin-Kazimierz Dolny, 12-14 czerwca 2006 r. [on-line]. [Warszawa] 2006 (EBIB Materiały konferencyjne; nr 14) [dostęp 15 lipca 2009]. Dostępny w World Wide Web: http://www.ebib.info/publikacje/matkonf/25kpbm/grygorowicz_kraszewska_1.php. 
funkcjonujące w światach typu Second Life. Wiele jednak wskazuje na to, że fizyczność bibliotek nie zaniknie. Nie wszystkie ich funkcje można bowiem realizować zdalnie, a zakres udostępniania wielu źródeł ogranicza prawo i licencja użytkowania. Nigdy też nawet najlepszej jakości wirtualny obraz nie zastąpi rzeczywistego eksponatu. Usługi zdalne i hybrydowe trzeba więc postrzegać jako szansę na usprawnienie pracy bibliotekarzy i podniesienie jakości prowadzenia działalności bibliotecznej. Nie należy ich demonizować i traktować jako zagrożenia dla istnienia bibliotek.

\section{Załącznik}

\section{Wykaz adresów stron internetowych polskich bibliotek uniwersyteckich [stan na dzień 15 lipca 2009 r.]}

1. Biblioteka Główna Uniwersytetu Gdańskiego: http://www.bg.univ.gda. $\mathrm{pl} /$.

2. Biblioteka Główna Uniwersytetu Kazimierza Wielkiego: http://biblioteka.ukw.edu.pl/.

3. Biblioteka Główna Uniwersytetu Marii Curie-Skłodowskiej: http://www. bg.umcs.lublin.pl/nowa/.

4. Biblioteka Główna Uniwersytetu Opolskiego: http://www.bg.uni.opole. $\mathrm{pl} /$.

5. Biblioteka Główna Uniwersytetu Szczecińskiego: http://bg.univ.szczecin.pl/index.php.

6. Biblioteka Jagiellońska: http://www.bj.uj.edu.pl/.

7. Biblioteka Uniwersytecka w Białymstoku: http://bg.uwb.edu.pl/.

8. Biblioteka Uniwersytecka w Olsztynie: http://bart.uwm.edu.pl/bibgw/ $\mathrm{pl} /$ index.php.

9. Biblioteka Uniwersytecka w Poznaniu: http://lib.amu.edu.pl/.

10. Biblioteka Uniwersytecka w Toruniu: http://www.bu.uni.torun.pl/index.html.

11. Biblioteka Uniwersytecka w Warszawie: http://www.buw.uw.edu.pl/.

12. Biblioteka Uniwersytecka w Zielonej Górze: http://www.bu.uz.zgora.pl/.

13. Biblioteka Uniwersytecka we Wrocławiu: http://www.bu.uni.wroc.pl/.

14. Biblioteka Uniwersytetu Kardynała Stefana Wyszyńskiego w Warszawie: http://www.biblioteka.uksw.edu.pl/.

15. Biblioteka Uniwersytetu Łódzkiego: http://www.lib.uni.lodz.pl/.

16. Biblioteka Uniwersytetu Rzeszowskiego: http://bur.univ.rzeszow.pl/.

17. Biblioteka Uniwersytetu Śląskiego: http://www.bg.us.edu.pl/. 


\section{Remote services in Polish university libraries}

Abstract

An academic library plays a significant part in the formation of information society realized by information and educational services. The task of a scientific library is to bring closer new information technologies, to create information supplies and then to make them available to wide groups of users. Changes taking place in higher educational system which include the transition from "teaching" to "learning", new directions and didactic forms, teaching on distance and the management of information require the change of the organization of work in academic libraries. An aim of the article is to collect and classify examples of new services, that is remote (especially electronic) services implementation into Polish university libraries. There has been seventeen universities' libraries analyzed. The author describes the services according to their suitability for libraries activity and to their possibilities. 